\title{
Preliminary results of ionic concentrations in snow pits along the Zhongshan-Dome A traverse route, Antarctica
}

\author{
REN Jiawen, SUN Junying, QIN Dahe \\ Key Laboratory of Ice Core and Cold Regions Environment, Cold and Arid Regions Environmental and Engineering Research \\ Institute, Chinese Academy of Sciences, 260 Donggang West Road, Lanzhou 730000, China \\ E-mail: jwren@ns.Izb.ac.cn
}

\begin{abstract}
During an inland traverse expedition along the route from Zhongshan station on the coast to Dome A (about $4200 \mathrm{~m}$ a.s.l.; $1400 \mathrm{~km}$ from Zhongshan) in East Antarctica in 1998/99, three snow pits with a depth of 2.1-3.3 m were sampled continuously. Snow pits were located at sites $800-1100 \mathrm{~km}$ from the coast, with altitudes varying from 2850 to $3760 \mathrm{~m}$. The samples were analyzed for stable oxygen isotope and major ions. Seasonal variations in $\delta^{18} \mathrm{O}$ are not clear, so initial dating was made through comparison of concentration profiles of major ions and then adjusted according to the visible stratigraphy. Generally, average ionic concentrations decrease with increasing altitude and hence distance from the coast, but $\mathrm{NH}^{4+}$ and $\mathrm{Ca}^{2+}$ have relatively high values at a site $1000 \mathrm{~km}$ inland. lonic concentrations tend to increase with depth at lower altitudes, but the opposite is true at higher altitudes. Accumulation rates increase with depth at site DT401 (3760 ma.s.l.; $1097 \mathrm{~km}$ from Zhongshan) and decrease at DT364 (3380 ma.s.I.; $1022 \mathrm{~km}$ from Zhongshan) and DT263 $(2850 \mathrm{~m}$ a.s.l.; $820 \mathrm{~km}$ from Zhongshan), suggesting that differences in regional trends exist. In all snow pits, $\mathrm{Na}^{+}$and $\mathrm{Cl}^{-}$ concentration profiles have a very good positive correlation. Profiles of $\mathrm{nssSO}_{4}{ }^{2-}$ in the pits show quite different features. At $3760 \mathrm{~m}$ a.s.l, no remarkable $\mathrm{nssSO}_{4}{ }^{2-}$ peaks can be distinguished, but one and three peak sets are quite striking at 3380 and $2850 \mathrm{~m}$, respectively.
\end{abstract}

\section{INTRODUCTION}

Permanently ice-covered regions of the world preserve a unique and datable record of the past composition of the Earth's atmosphere due to incorporation of trace quantities of water-soluble and insoluble substances in snow/ice during both precipitating and non-precipitating periods (Clausen and Langway, 1989; Peel, 1989). Thus, one may reveal the history of the atmospheric environment at a specific site through chemical analysis of snow/ice samples collected continuously in a glacier or ice sheet. In the Antarctic ice sheet, such work has been carried out at many places for various time-scales. Due to the complexity of climate and vastness of the ice sheet, however, this type of work is still necessary at new sites and also at previously investigated places, particularly for short-time-scale studies with high resolution, to understand the modern atmospheric and snow-chemistry compositions as well as regional differences. Glaciochemical and other glaciological studies are very sparse in the inland regions of the Antarctic ice sheet, especially in the central part of the East Antarctic plateau, so new work is much needed.

In recent years, the Chinese National Antarctic Research Expedition (CHINARE) has initiated an inland glaciological investigation program along a traverse route from Zhongshan station on the coast $\left(69^{\circ} 22^{\prime} \mathrm{S}, 76^{\circ} 23^{\prime} \mathrm{E}\right)$ to Dome A (about $81.5^{\circ} \mathrm{S}, 77^{\circ} \mathrm{E} ; 4200 \mathrm{~m}$ a.s.l.; $1400 \mathrm{~km}$ from Zhongshan). During these expeditions, the traverse route has been extended southwards to $1100 \mathrm{~km}$ inland in the central area of the East Antarctic plateau (Fig. 1), and firn/ice cores with a depth range of $50-100 \mathrm{~m}$ were drilled at several sites. Additionally, snow pits with 2-3.3 m depths were sampled at some sites. To date, studies of the cores and snow pits from the coast to $500 \mathrm{~km}$ inland have shown the regime of climate variations over the past 250 years in Princess Elizabeth Land, and regional differences in climate between the west and east sides of Lambert Glacier, reported elsewhere ( $\mathrm{Li}$ and others, 1999; Qin and others, 2000; Xiao and others, 2001; Zhang and others, 2001, 2002; Ren and others, 2002). Dating analysis for the cores drilled 800 and about $1100 \mathrm{~km}$ inland is not finished yet. In this paper, we present preliminary results of three snow-pit sites, with emphasis on the ionic concentrations.

\section{SAMPLING AND EXPERIMENTAL ANALYSIS}

Figure 1 shows the Zhongshan station-Dome A investigation route and the location of the sampling sites. The longest traverse from the coast, from Zhongshan station to DT401 $\left(79^{\circ} 00^{\prime} \mathrm{S}, 77^{\circ} 00^{\prime} \mathrm{E} ; 3760 \mathrm{~m}\right.$ a.s.l.; $1097 \mathrm{~km}$ from Zhongshan) was carried out in the austral summer from December 1998 to February 1999. During this traverse, snow pits were dug to depths of 3.3, 2.1 and $2.4 \mathrm{~m}$ at sites DT401, DT364 ( $78^{\circ} 20^{\prime} \mathrm{S}, 77^{\circ} 00^{\prime} \mathrm{E} ; 3380 \mathrm{~m}$ a.s.l.; $1022 \mathrm{~km}$ from Zhongshan) and DT263 $\left(76^{\circ} 32^{\prime} \mathrm{S}, 77^{\circ} 01^{\prime} \mathrm{E} ; 2850 \mathrm{~m}\right.$ a.s.l.; $820 \mathrm{~km}$ from Zhongshan), respectively. At each pit, snow was sampled continuously from the bottom to the surface by pushing a $120 \mathrm{~mL}$ pre-cleaned plastic bottle into the leeward wall of the pit, each sample covering a depth interval of $3 \mathrm{~cm}$. At DT401, DT364 and DT263 sites, respectively, 110, 70 and 80 samples were obtained. Visible stratigraphy was described for the sampled wall of each pit. In addition, four aerosol samples were collected at DT401, and two samples at DT263. The aerosol study results were partially reported by Sun (2002) and will be discussed further elsewhere.

Snow samples were kept frozen during transport and stored at about $-15^{\circ} \mathrm{C}$ prior to laboratory analysis. Analyses were carried out for anions $\left(\mathrm{Cl}^{-}, \mathrm{NO}_{3}{ }^{-}, \mathrm{SO}_{4}{ }^{2-}\right)$, cations $\left(\mathrm{Na}^{+}\right.$, $\left.\mathrm{NH}_{4}^{-}, \mathrm{K}^{+}, \mathrm{Mg}^{2+}, \mathrm{Ca}^{2+}\right)$ and stable isotopes $\left(\delta^{18} \mathrm{O}\right)$. Ion concentrations were measured using a Dionex Model DX-600 ion chromatograph for cations and a DX-300 for 


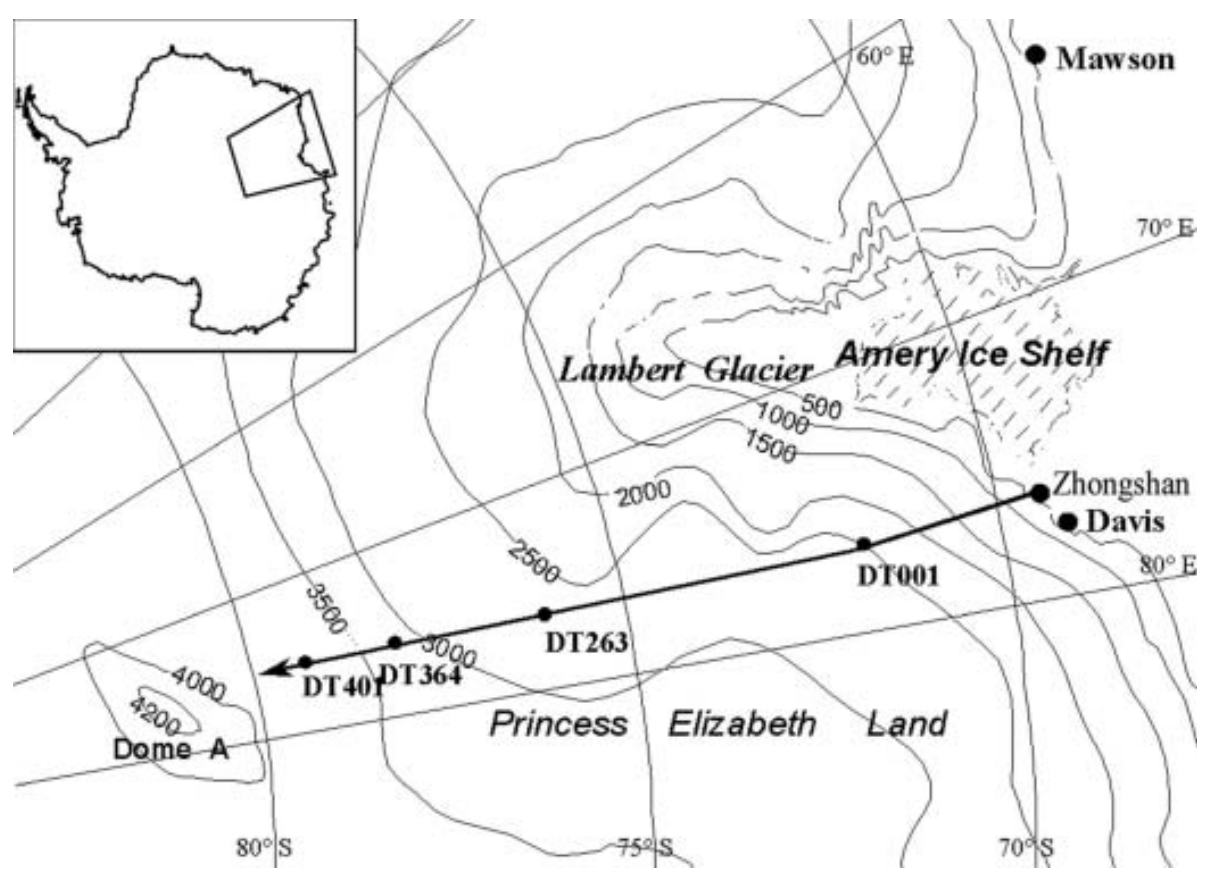

Fig. 1. Map showing the Zhongshan-Dome A traverse route and location of sampling sites.

anions, with a detection limit of $1 \times 10^{-9} \mathrm{~g} \mathrm{~g}^{-1}$. Five blank samples were measured and the average values for all blanks were $<0.1 \mu \mathrm{eqL} \mathrm{L}^{-1}$, so errors are $<5 \%$. $\delta^{18} \mathrm{O}$ measurements were made using a MAT-252 gas stable-isotope ratio mass spectrometer, with a precision of $\pm 0.5 \%$. All the measurements were conducted at the Key Laboratory of Ice Core and Cold Regions Environment, Cold and Arid Regions Environmental Research Institute (formerly Lanzhou Institute of Glaciology and Geocryology), Chinese Academy of Sciences.

\section{DATING}

Dating is critical in stratigraphic studies of snow and ice. In Antarctica, various dating techniques have been used to establish the depth-age relationship in ice cores. Among them, seasonal variations of physical and chemical parameters and reference horizons are the most important for shallow cores and snow pits. Due to a very low snowaccumulation rate in our study area, $\delta^{18} \mathrm{O}$ profiles do not provide definite information on seasonal layers, although some variations can be seen (Fig. 2). In our snow pits the average annual layer is estimated to vary from 10 to $20 \mathrm{~cm}$ in snow depth, so the radioactive reference horizons produced by thermonuclear tests in the 1950s and early 1960s cannot be detected within a depth of $3.3 \mathrm{~m}$.

Visible stratigraphic profiles help in identifying annual layers in inland Antarctica in spite of much uncertainty in the interpretation of the various stratigraphic features observed (Shoji and Langway, 1989). From observations in more than ten snow pits in the Lambert Glacier basin, Ren and others (1995) concluded that solar radiation crusts are summer layer indicators. On the other hand, studies of snow pits and firn cores within the first $500 \mathrm{~km}$ along the Zhongshan-Dome A traverse route show that seasonal variations of some ions (e.g. $\mathrm{Na}^{+}, \mathrm{Cl}^{-}$and $\mathrm{NO}_{3}{ }^{-}$) are well preserved from the surface down to $50 \mathrm{~m}$ depth ( $\mathrm{Li}$ and others, 1999; Zhang and others, 2002).
At first we tried to date the snow pits using the ice crusts and each ionic concentration profile separately. Results show that ice crusts do not always correspond with peaks or troughs of ionic profiles. In general, a firn layer in between ice crusts matches one annual cycle of ionic concentration variations, except for $\mathrm{NO}_{3}{ }^{-}$and $\mathrm{NH}_{4}{ }^{+}$. In view of this, and considering that correlation between $\mathrm{Na}^{+}$and $\mathrm{Cl}^{-}$is better than between other ions, the annual-layer series were determined by taking the peaks of $\mathrm{Na}^{+}$and $\mathrm{Cl}^{-}$concentrations as winter indicators and then adjusted according to the presence of ice crusts, as shown in Figure 2. The error of this dating technique is estimated to be about $10 \%$.

According to dating and density measurements, these three pits represent 25,13 and 16 years of precipitation, and the accumulation rate on average is 60,76 and $70 \mathrm{~kg} \mathrm{~m}^{-2} \mathrm{a}^{-1}$ at DT401, DT364 and DT263, respectively. Figure 3 illustrates the accumulation-rate variations in these pits.

\section{IONIC CONCENTRATIONS}

Concentration profiles of $\mathrm{Na}^{+}$and $\mathrm{Cl}^{-}$in the snow pits are shown against depth in Figure 2. The derived time-scales, and $\mathrm{NO}_{3}{ }^{-}$and $\mathrm{nsSO}_{4}{ }^{2-}$ are shown in Figures 4 and 5, respectively. Concentrations of $\mathrm{K}^{+}, \mathrm{Mg}^{2+}$ and $\mathrm{Ca}^{2+}$ are

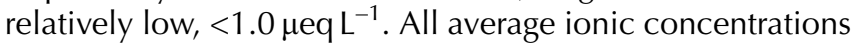
and the $\mathrm{Cl}^{-} / \mathrm{Na}^{+}$ratio in these three pits are given in Table 1. For the sake of comparison, results at two snow pits at similar altitudes in other regions of East Antarctica are also quoted. One of these pits was sampled in late 1989 along a route from South Pole to Vostok (SP-V) (Qin, 1995); the other was sampled in the austral summer of 1993/94 in Dronning Maud Land (Stenberg and others, 1998).

It is interesting to note that $\mathrm{NO}_{3}{ }^{-}$concentrations are much lower than those of other ions, being $<0.1 \mu \mathrm{eq} \mathrm{L}^{-1}$ in more than half of the samples in the pit at DT401, but comparable to $\mathrm{Na}^{+}$concentrations at DT263. Very high values in the uppermost $10 \mathrm{~cm}$ (the concentration of the first two samples is 6.14 and $1.56 \mu \mathrm{eq} \mathrm{L}^{-1}$, respectively) cause a 

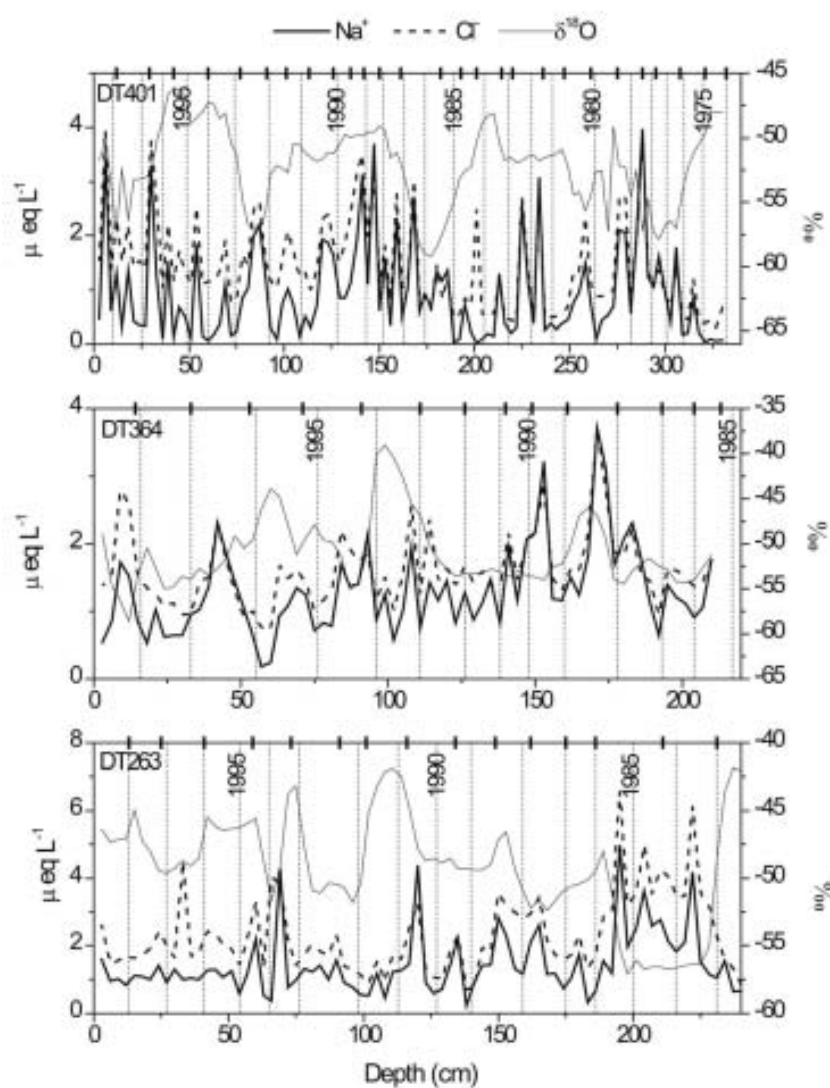

Fig. 2. Profiles of $\mathrm{Na}^{+}, \mathrm{Cl}^{-}$and $\delta^{18} \mathrm{O}$ compared with the ice-crust distribution (vertical bars on the upper coordinate axis). Annual layers from 1974 to 1998 are shown as vertical dotted lines in snow pits at DT401, DT364 and DT263, identified as explained in the text.

moderate average concentration of $\mathrm{NO}_{3}{ }^{-}$at DT401. This phenomenon also occurs at DT364 and on the SP-V route (Qin, 1995), but does not occur at DT263.

Very high $\mathrm{NO}_{3}{ }^{-}$concentrations in the uppermost surface layers and rapid decay at depth have also been reported at a few other sites on the East Antarctic plateau, such as Dome $\mathrm{C}$ and Vostok, and at the South Pole (Mayewski and Legrand, 1990; Whitlow and others, 1992; Dibb and Whitlow, 1996). These results suggest that $\mathrm{NO}_{3}{ }^{-}$is unstable and a great part of it may be lost by re-emission back to the atmosphere within 1 year in the central parts of East Antarctica.

$\mathrm{NO}_{3}{ }^{-}$content in polar snow is believed to be affected by photolysis and lightning (Clausen and Langway, 1989). Jones and others (2000) and Dominé and Shepson (2002) have discussed photolysis of $\mathrm{NO}_{x}$ in snow of Greenland and Antarctica. They have modelled the snowpack as a multiphase reactor in which physical exchange processes, heterogeneous reactions and photochemical reactions take place, but lack of quantitative understanding still hampers efforts to simulate these snowpack processes. Since reports of post-depositional loss of $\mathrm{NO}_{3}{ }^{-}$in Antarctic snow are few, and the results between our pits strikingly different, we hope to collect further data and perform future investigations during the next traverses in the region.

Comparison of average ionic concentrations in various snow pits in Table 1 shows that concentrations of most ions decrease with increasing altitude and hence distance from the coast along the traverse route. It is difficult to explain the
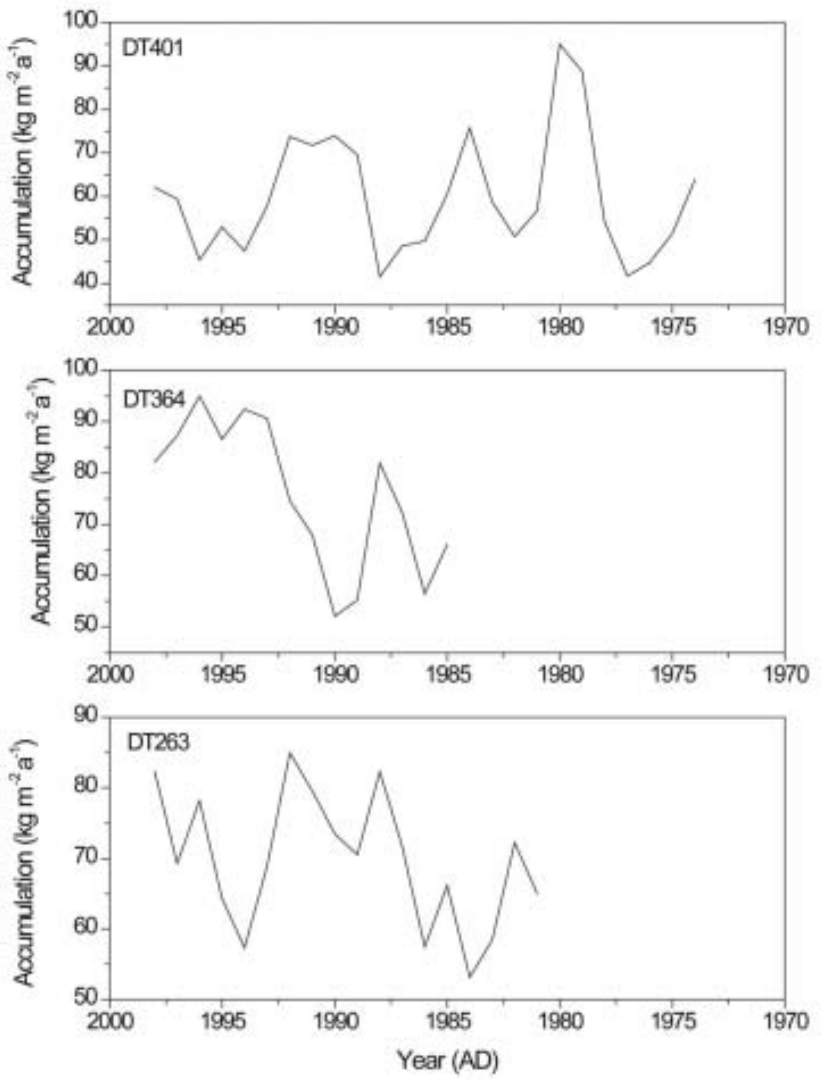

Fig. 3. Variations of the accumulation rate at DT401, DT364 and DT263.

relatively high present values of $\mathrm{NH}_{4}{ }^{+}$and $\mathrm{Ca}^{2+}$ at DT364. In general, concentrations of the main ions (e.g. $\mathrm{Na}^{+}, \mathrm{Cl}^{-}$and $\mathrm{SO}_{4}{ }^{2-}$ ) in our snow pits are comparable to measurements in Dronning Maud Land and on the route from South Pole to Vostok (Qin, 1995). On the other hand, $\mathrm{NH}_{4}{ }^{+}$is much higher along the Zhongshan-Dome A route than along the South Pole-Vostok route, and $\mathrm{NO}_{3}{ }^{-}$is strikingly low at DT401 and DT364.

From Figures 2, 4 and 5 we can see that major-ionic concentrations increase with depth at DT263, the opposite is true at DT401 and no clear trend is apparent at DT364. This suggests that ionic concentrations have been increasing in recent decades at high altitudes and decreasing at lower altitudes, with a transition zone at around 3400 ma.s.l. Since ionic concentrations are inversely proportional to the snow accumulation rate, if constant flux is assumed, this points to a regional difference in the snow accumulation variation (i.e. a decreasing accumulation rate near the plateau top and increasing rate at lower altitudes in the past two decades). Indeed, an accumulation-rate increase in recent years at DT263 and DT364 and decrease at DT401 can be seen in Figure 3. In addition, an apparent increase in the snow accumulation rate along the Zhongshan-Dome A traverse route in the past decades from the coast to a site $500 \mathrm{~km}$ inland, at altitudes lower than $2600 \mathrm{~m}$, has also been revealed by shallow-core studies (Xiao and others, 2001; Ren and others, 2002).

On the other hand, ionic fluxes may also have changed with time in the past due to atmospheric circulation variations. At the South Pole, for example, it was reported 

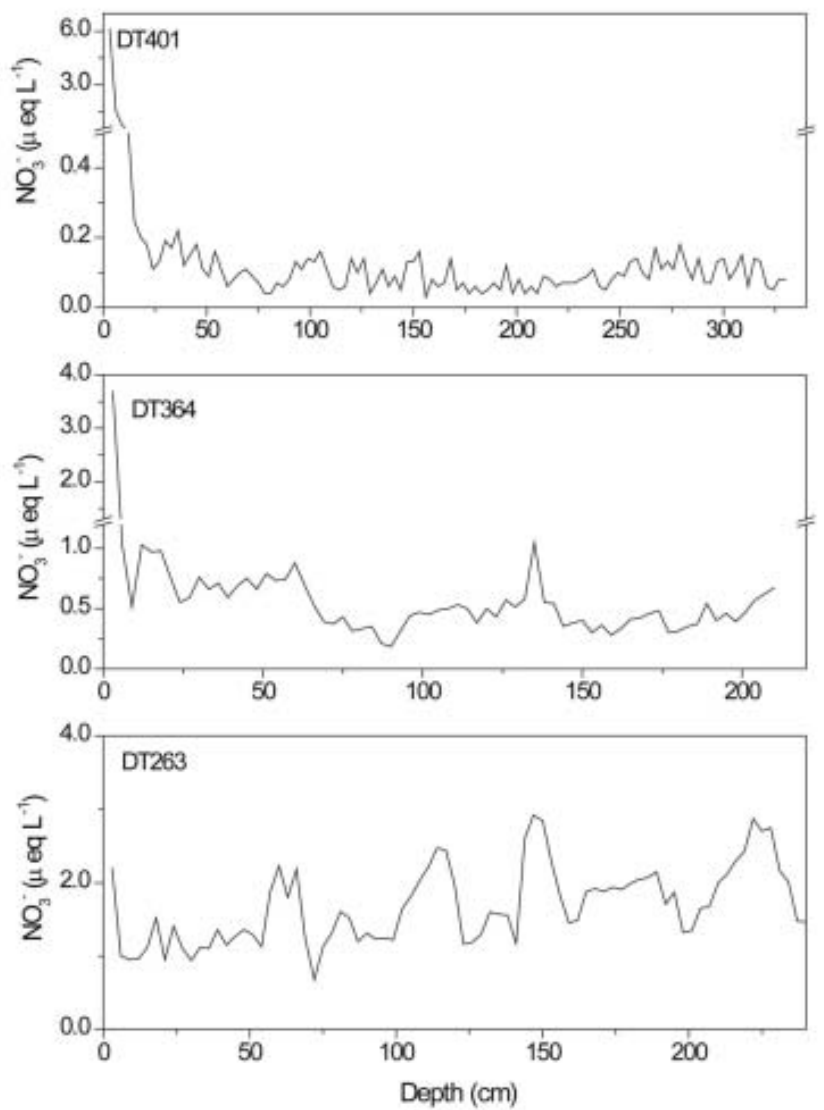

Fig. 4. $\mathrm{NO}_{3}{ }^{-}$concentration profiles in snow pits at DT401, DT364 and DT263. The time markers are derived from Figure 2 as explained in the text.

that accumulation rate increased during the period from the 1950s to the 1980s (Mosley-Thompson and others, 1995), and concentrations of most ions, except $\mathrm{NO}_{3}{ }^{-}$, had basically no changes (Mayewski and Legrand, 1990; Whitlow and others, 1992; Legrand and Mayewski, 1997).

\section{Non-sea-salt sulphates}

In Antarctica, $\mathrm{nssSO}_{4}{ }^{2-}$ peaks have been taken as an indicator of volcanic eruptions in ice-core records. In East Antarctica, volcanic eruptions have been identified from $\mathrm{nssSO}_{4}{ }^{2-}$ data in snow and ice at the South Pole (Delmas and others, 1992; Cole-Dai and others, 1997), in Remote Plateau $\left(84^{\circ} \mathrm{S}, 43^{\circ} \mathrm{E}\right.$; Cole-Dai and others, 2000) and in Princess Elizabeth Land (at DT001 along the ZhongshanDome A route, $270 \mathrm{~km}$ inland and $2325 \mathrm{~m}$ a.s.l.) (Zhang and
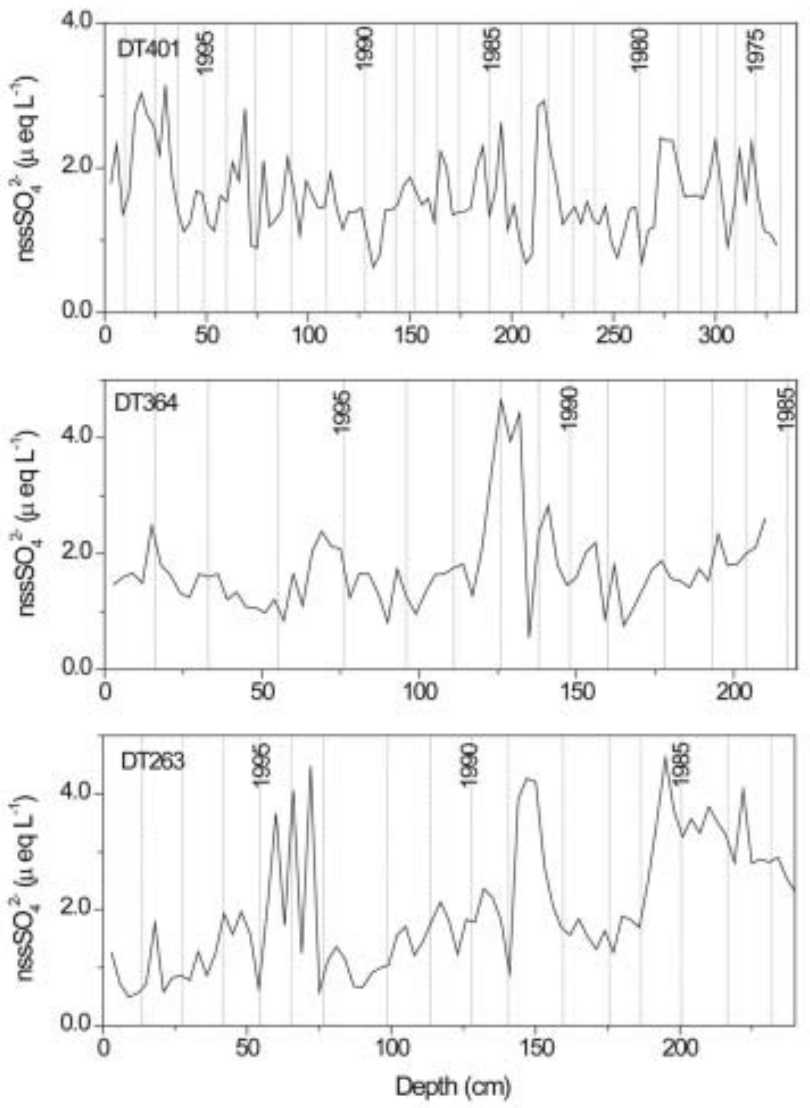

Fig. 5. $\mathrm{nssSO}_{4}{ }^{2-}$ concentration profiles in snow pits at DT401, DT364 and DT263. The time markers were derived from Figure 2 as explained in the text.

others, 2002). Figure 4 gives profiles of $\mathrm{nssSO}_{4}{ }^{2-}$ variations with depth and hence with time. It can be seen from these profiles that it is hard to identify any volcanic eruptions at DT401. But there is a striking peak in the profile at DT364. It is dated to be around 1993, possibly a signal of the Pinatubo (Philippines) and Hudson (Chile) eruptions in 1991. Pinatubo's eruption was the largest in the 1990s (Krueger and others, 1995) and has been detected around 1993 in ice cores at many sites in Antarctica, such as at South Pole (Cole-Dai and others, 1997) and especially at DT001 (Zhang and others, 2002). The 1991 Hudson eruption was much smaller (Doiron and others, 1991) and was detected in 1992 at DT001 (Zhang and others, 2002). The DT263 profile displays three sets of high $\mathrm{nssO}_{4}{ }^{2-}$ values, corresponding approximately to 1994-95, 1989 and

Table 1. Average values of ionic concentrations in snow pits $\left(\mu \mathrm{eq} \mathrm{L}^{-1}\right)$

\begin{tabular}{|c|c|c|c|c|c|c|c|c|c|c|c|}
\hline Site & Location & $\begin{array}{l}\text { Altitude } \\
\mathrm{m}\end{array}$ & $\mathrm{Na}^{+}$ & $\mathrm{NH}_{4}^{+}$ & $\mathrm{K}^{+}$ & $\mathrm{Mg}^{2+}$ & $\mathrm{Ca}^{2+}$ & $\mathrm{Cl}^{-}$ & $\mathrm{NO}_{3}{ }^{-}$ & $\mathrm{SO}_{4}{ }^{2-}$ & $\mathrm{Cl}^{-} / \mathrm{Na}^{+}$ \\
\hline DT401 & $79^{\circ} 00^{\prime} \mathrm{S}, 77^{\circ} 00^{\prime} \mathrm{E}$ & 3760 & 0.94 & 0.88 & 0.22 & 0.21 & 0.70 & 1.45 & 0.18 & 1.73 & 1.55 \\
\hline DT364 & $78^{\circ} 20^{\prime} \mathrm{S}, 77^{\circ} 00^{\prime} \mathrm{E}$ & 3380 & 1.31 & 1.40 & 0.32 & 0.35 & 0.93 & 1.63 & 0.58 & 1.90 & 1.24 \\
\hline DT263 & $76^{\circ} 32^{\prime} \mathrm{S}, 77^{\circ} 01^{\prime} \mathrm{E}$ & 2850 & 1.45 & 1.14 & 0.36 & 0.43 & 0.48 & 2.34 & 1.69 & 2.18 & 1.61 \\
\hline $\mathrm{DML}^{\dagger}$ & $75^{\circ} 30^{\prime} \mathrm{S}, 02^{\circ} 41^{\prime} \mathrm{E}$ & 3100 & 0.60 & - & - & 0.21 & - & 0.98 & 0.93 & 2.05 & 2.10 \\
\hline
\end{tabular}


1984-86, respectively. It is questionable whether these peaks all indicate volcanic eruptions. If the upper and lower peak sets are regarded as signals of Pinatubo (plus Hudson) and possibly El Chichón (Mexico; $17.3^{\circ} \mathrm{N}, 93.2^{\circ} \mathrm{W}$ ) eruptions, respectively, the 1989 peak does not have a corresponding volcano event. It was estimated that the El Chichón eruption in 1982 loaded $7 \pm 2 \mathrm{Mt}$ of $\mathrm{SO}_{4}$ into the atmosphere (Bluth and others, 1992), smaller than the Pinatubo eruption but larger than the Hudson eruption. However, this eruption has not been detected at DT001 (Zhang and others, 2002), only $500 \mathrm{~km}$ from DT263. More data are needed to confirm and further investigate the large differences between the three pit sites and whether the nssSO ${ }_{4}^{2-}$ could be taken as an indicator of volcano events in this area.

\section{CONCLUSIONS}

Preliminary results of three snow pits at altitudes of 2850 $3760 \mathrm{~m}$ (800-1100 km from the coast, respectively) show some apparent differences in ionic concentrations. At $3760 \mathrm{~m}$ a.s.l., average ionic concentrations are lower and have increased in the last two decades. Unusually high concentrations of $\mathrm{NO}_{3}{ }^{-}$are detected at 3760 ma.s.l., with values of 6.14 and $1.56 \mu \mathrm{eq} \mathrm{L^{-1 }}$ in the uppermost $10 \mathrm{~cm}$, and an average concentration of all samples of $0.18 \mu \mathrm{eq} \mathrm{L}^{-1}$. At $2850 \mathrm{~m}$ a.s.l. the opposite is true, i.e. the average ionic concentrations are relatively higher, ionic concentrations have decreased during the last 20 years and there is no remarkably high $\mathrm{NO}_{3}{ }^{-}$concentration near the surface. At $3380 \mathrm{~m}$ a.s.l. the average ionic concentrations are moderate; the $\mathrm{NO}_{3}{ }^{-}$values are similar at 3380 and $3760 \mathrm{~m}$ a.s.l., i.e. concentration of the near-surface samples is strikingly high with a concentration of 3.69 and $1.02 \mu \mathrm{eq} \mathrm{L}^{-1}$ in the upper $10 \mathrm{~cm}$, and an average concentration of all samples of $0.58 \mu \mathrm{eq} \mathrm{\textrm {L } ^ { - 1 }}$ at $3380 \mathrm{~m}$ a.s.I. Ionic concentration values at $3380 \mathrm{~m}$ a.s.l. have no definite temporal trend. The snow accumulation rate also has opposite trends depending upon site altitude. Accumulation rates have increased at $3380 \mathrm{~m}$ a.s.l. from about $60 \mathrm{~kg} \mathrm{~m}^{-2} \mathrm{a}^{-1}$ in the $1980 \mathrm{~s}$ to about $90 \mathrm{~kg} \mathrm{~m}^{-2} \mathrm{a}^{-1}$ in the 1990s, and from about $60 \mathrm{~kg} \mathrm{~m}^{-2} \mathrm{a}^{-1}$ to $80 \mathrm{~kg} \mathrm{~m}^{-2} \mathrm{a}^{-1}$ at $2850 \mathrm{~m}$ a.s.l., while at $3760 \mathrm{~m}$ a.s.l. they have decreased from about $70 \mathrm{~kg} \mathrm{~m}^{-2} \mathrm{a}^{-1}$ in the mid-1970s and mid-1980s to about $60 \mathrm{~kg} \mathrm{~m}^{-2} \mathrm{a}^{-1}$ in the late 1990s. The $\mathrm{nssSO}_{4}{ }^{2-}$ profiles in snow pits also display different features at the three sites: at 3760 ma.s.l. no remarkable nssSO $_{4}{ }^{2-}$ peaks can be distinguished, but one and three peak sets are quite striking at 3380 and $2850 \mathrm{~m}$, respectively. These data indicate a difference in atmospheric circulation over the plateau top and over the lower-altitude region, with important regional differences in snow chemistry and snow-accumulation variation, and a transition zone at around $3400 \mathrm{~m}$ a.s.I. More data are needed to confirm the regional trends and to explain the processes of snow-air interaction, atmospheric chemistry and atmospheric circulation.

\section{ACKNOWLEDGEMENTS}

This work was supported by the Ministry of Science and Technology of China (grant No. 2001CB711003, 2001DIA50040), the Chinese Academy of Sciences (grant No. KZCX2-303) and the National Natural Science Foundation of China (grant No. 49971021, 40071025).

\section{REFERENCES}

Bluth, G. J. S., S. D. Doiron, C. C. Schnetzler, A. J. Krueger and L. S. Walter. 1992. Global tracking of the $\mathrm{SO}_{2}$ clouds from the June 1991 Mount Pinatubo eruptions. Geophys. Res. Lett., 19(2), 151-154.

Clausen, H. B. and C. C. Langway, Jr. 1989. The ionic deposits in polar ice cores. In Oeschger, H. and C. C. Langway, Jr, eds. The environmental record in glaciers and ice sheets. Chichester, etc., John Wiley and Sons, 225-247.

Cole-Dai, J., E. Mosley-Thompson and L. G. Thompson. 1997. Annually resolved Southern Hemisphere volcanic history from two Antarctic ice cores. J. Geophys. Res., 102(D14), 16,76116,771 .

Cole-Dai, J., E. Mosley-Thompson, S. P. Wight and L. G. Thompson. 2000. A 4100-year record of explosive volcanism from an East Antarctic ice core. J. Geophys. Res., 105(D19), 24,431-24,441.

Delmas, R. J., S. Kirchner, J. M. Palais and J.-R. Petit. 1992. 1000 years of explosive volcanism recorded at the South Pole. Tellus, 44B(4), 335-350.

Dibb, J. E. and S. I. Whitlow. 1996. Recent climatic anomalies and their impact on snow chemistry at South Pole, 1987-1994. Geophys. Res. Lett., 23(10), 1115-1118.

Doiron, S. D., G. J. S. Bluth, C. C. Schnetzler, A. J. Krueger and L. S. Walter. 1991. Transport of Cerro Hudson $\mathrm{SO}_{2}$ clouds. Eos, 72(45), 489-490.

Dominé, F. and P. B. Shepson. 2002. Air-snow interactions and atmospheric chemistry. Science, 297(5586), 1506-1510.

Jones, A. E., R. Weller, E. W. Wolff and H.-W. Jacobi. 2000. Speciation and rate of photochemical $\mathrm{NO}$ and $\mathrm{NO}_{2}$ production in Antarctic snow. Geophys. Res. Lett., 27(3), 345-348.

Krueger, A. J. and 6 others. 1995. Volcanic sulfur dioxide measurements from the total ozone mapping spectrometer instruments. J. Geophys. Res., 100(D7), 14,057-14,076.

Legrand, M. and P. Mayewski. 1997. Glaciochemistry of polar ice cores: a review. Rev. Geophys., 35(3), 219-243.

Li Zhongqin, M. J. Zhang, Qin Dahe, Xiao Cunde, Kang Jiancheng and Li Jun. 1999. [Primary research on the seasonal variations of $\delta^{18} \mathrm{O}, \mathrm{Cl}^{-}, \mathrm{NO}_{3}{ }^{-}, \mathrm{Na}^{+}$and $\mathrm{Ca}^{2+}$ in the snow and firn recovered from Princess Elizabeth Land, Antarctica.] [Chin. Sci. Bull.], 44(24), 2270-2274. [In Chinese with English abstract.]

Mayewski, P. A. and M. Legrand. 1990. Recent increase in nitrate concentration of Antarctic snow. Nature, 346(6281), 258-260.

Mosley-Thompson, E. and 6 others. 1995. Recent increase in South Pole snow accumulation. Ann. Glaciol., 21, 131-138.

Peel, D. A. 1989. Trace metals and organic compounds in ice cores. In Oeschger, H. and C. C. Langway, Jr, eds. The environmental record in glaciers and ice sheets. Chichester, etc., John Wiley and Sons, 207-223.

Qin Dahe. 1995. [Report on glaciological research of the 1990 International Trans-Antarctic Expedition (1989-1994).] Beijing, Science Press. Chinese Academy of Sciences. Lanzhou Institute of Glaciology and Geocryology. [In Chinese.]

Qin Dahe and 8 others. 2000. Primary results of glaciological studies along an $1100 \mathrm{~km}$ transect from Zhongshan station to Dome A, East Antarctic ice sheet. Ann. Glaciol., 31, 198-204.

Ren Jiawen, Qin Dahe, I. Allison, M. Higham and I. D. Goodwin. 1995. [A study of snow stratigraphy and accumulation-rate change in the west part of the Lambert Glacier basin, East Antarctica.] J. Glaciol. Geocryol., 17(3), 274-282. [In Chinese with English summary.]

Ren Jiawen, Qin Dahe, Xiao Cunde, Sun Junying, Li Zhongqin and Zhang Mingjun. 2002. [Comparison of ice-core records of climatic change over past centuries in Antarctica.] J. Glaciol. Geocryol., 24(5), 484-491.

Shoji, H. and C. C. Langway, Jr. 1989. Physical property reference horizons. In Oeschger, H. and C. C. Langway, Jr, eds. The environmental record in glaciers and ice sheets. Chichester, etc., John Wiley and Sons, 161-175. 
Stenberg, M. and 7 others. 1998. Spatial variability of snow chemistry in western Dronning Maud Land, Antarctica. Ann. Glaciol., 27, 378-384.

Sun Junying. 2002. [Study on chemistry of aerosols and snow/ice from cryosphere-cases study at the Antarctic, the Arctic and western China.] (Ph.D. thesis, Lanzhou. Chinese Academy of Sciences, Cold and Arid Regions Environmental and Engineering Research Institute.) [In Chinese with English summary.]

Whitlow, S., P. A. Mayewski and J. E. Dibb. 1992. A comparison of major chemical species seasonal concentration and accumulation at the South Pole and Summit, Greenland. Atmos. Environ., 26A(11), 2045-2054.
Xiao Cunde, Ren Jiawen, Qin Dahe, Li Hongqin, Sun Weizhen and I. Allison. 2001. Correspondence. Complexity of the climatic regime over the Lambert Glacier basin of the East Antarctic ice sheet: firn-core evidences. J. Glaciol., 47(156), 160-162.

Zhang Mingjun, Li Zhongqin, Qin Dahe and others. 2001. Accumulation and temperature changes in Princess Elizabeth Land, Antarctica in the past 250 years. [Progress in Natural Sciencel, 11(7), 523-528.

Zhang, M. J. and 6 others. 2002. A continuous 250-year record of volcanic activity from Princess Elizabeth Land, East Antarctica. Antarct. Sci., 14(1), 55-60. 